\title{
ANTHIAS HUTOMOI, A NEW SPECIES OF \\ SERRANID FISH FROM INDONESIA (PERCIFORMES, SERRANIDAE) ${ }^{1}$ )
}

\author{
by \\ GERALD R. ALLEN ${ }^{2}$ ) and BURHANUdDiN ${ }^{3}$ )
}

(Manuscript received 16 September, 1975)

\begin{abstract}
Anthias hutomoi, a member of the family Serranidae (subfamily Anthiinae) is described from 11 specimens taken by trawl at Seram, Indonesia. It appears to be allied to Anthias cichlops (BLEEKER,), but differs in several important respects, including head length, caudal shape, and counts for the lateral-line, soft dorsal rays, and pectoral rays.
\end{abstract}

IKHTISAR

Anthias hutomoi, yang termasuk suku Serranidae (anak-suku Anthiinae), dipertelakan dari 11 ekor ikan yang ditangkap dengan "beam trawl" di pulau Seram, Indonesia. Tampaknya ikan ini sangat dekat dengan Anthias cichlops (BLEEKER), tetapi berbeda dalam panjang kepala, bentuk ekor, dan jumlah sisik pada garis lateral, duri lemah sirip punggung, dan duri lemah sirip dada.

\section{INTRODUCTION}

The subfamily Anthiinae contains relatively small, colourful fishes which inhabit Indo-Pacific reefs. The majority of species are found in the tropics, but the group contains several cool-water representatives which are mainly confined to southern Australia and New Zealand.

The fishes are poorly known, primarily because many of the species inhabit relatively deep water below depths normally frequented by SCUBA divers. At least 10 species remain undescribed among the material presently lodged at the Australian Museum (Sydney), B.P. Bishop Museum (Honolulu), and the Western Australian Museum (Perth).

$\left.{ }^{1}\right)$ Joined contribution of Western Australian Museum and the Lembaga Oseanologi

Nasional, Lembaga Ilmu Pengetahuan Indonesia.

2 Western Australian Museum, Francis Street, Perth, 6000.

3) Lembaga Oseanologi Nasional, Pasar Ikan, Jakarta. 


\section{G. R. Allen \& Burhanuddin}

During January - February 1975, the authors participated in the Rumphius Expedition II, a multi-disciplinary marine biological investigation of the southern Maluku islands. Approximately 500 species were taken by a variety of methods which included beam trawling, rotenone ichthyocide, quinaldine, and underwater spearing. The collections contain several new species of fish including a species of Anthias, which is described below. Type specimens have been deposited at the Lembaga Oseanologi Nasional (LON = National Institute of Oceanology), LIPI (Indonesian Institute of Sciences), Jakarta, and the Western Australian Museum, Perth (WAM).

\section{Anthias hutomoi new species}

(Fig. 1, Table I)

\section{Holotype}

$51.0 \mathrm{~mm}$ standard length; Seleman Bay, Seram, Maluku Islands, Indonesia, in 54 metres, beam trawl; coll. M. Hutomo, Burhanuddin and crew of Samudera, 19/1/1975; LON NCIP 3493.

\section{Paratypes}

6 specimens, 32.0-41.0 mm standard length; collected with holotype; LON NCIP 3494-3499; 4 specimens, 28.0-48.7 mm standard length; collected with holotype WAM P25199-001.

\section{Diagnosis}

A species of Anthias with the following combination of characters: Dorsal rays X, 13 to 15; anal rays III, 7; greatest body depth 2.9 to 3.0 in standard length; head length 2.8 to 3.1 in standard length; gill-rakers 34 to 36 (usually 25 to 26 on lower arch) ; two or three scale rows between dorsal fin and lateral-line; pored lateral-line scales 43 ton 47; third dorsal spine subequal to others; anal fin tip acute; caudal fin lunate.

\section{Description}

Counts and proportional measurements for the holotype are followed by the range for the paratypes in parentheses.

Dorsal rays X, 14 (X, 13 [1], X, 14 [7], X, 15 [2] ; anal rays III, 7; pectoral rays 17 (16 [4], 17 [6]); pored lateral-line scales 46 (43 [3], 44 [2], 46 [4], 47 [1]), scale rows between lateral-line and base of middle dorsal spines 2 (2 to 3 ); scale rows between lateral-line and origin of 
anal fin 15 (15 to 16 ); gill-rakers on first branchial arch $11+25=36$ (34 [1], 35 [7], 36 [1]).

Body relatively elongate, depth 3.0 (2.9 to 3.0 ) in standard length, and compressed, width 1.7 (1.8 to 2.0) in depth; head length contained 3.1 (2.8 to 3.1) in standard length; snout 4.2 (4.4 to 5.6), eye 3.1 (2.8 to 3.0), interorbital 3.9 (3.5 to 4.0), least depth of caudal peduncle 2.5 (2.4 to 2.8), length of caudal peduncle 2.4 (2.4 to 2.7), all in head length.

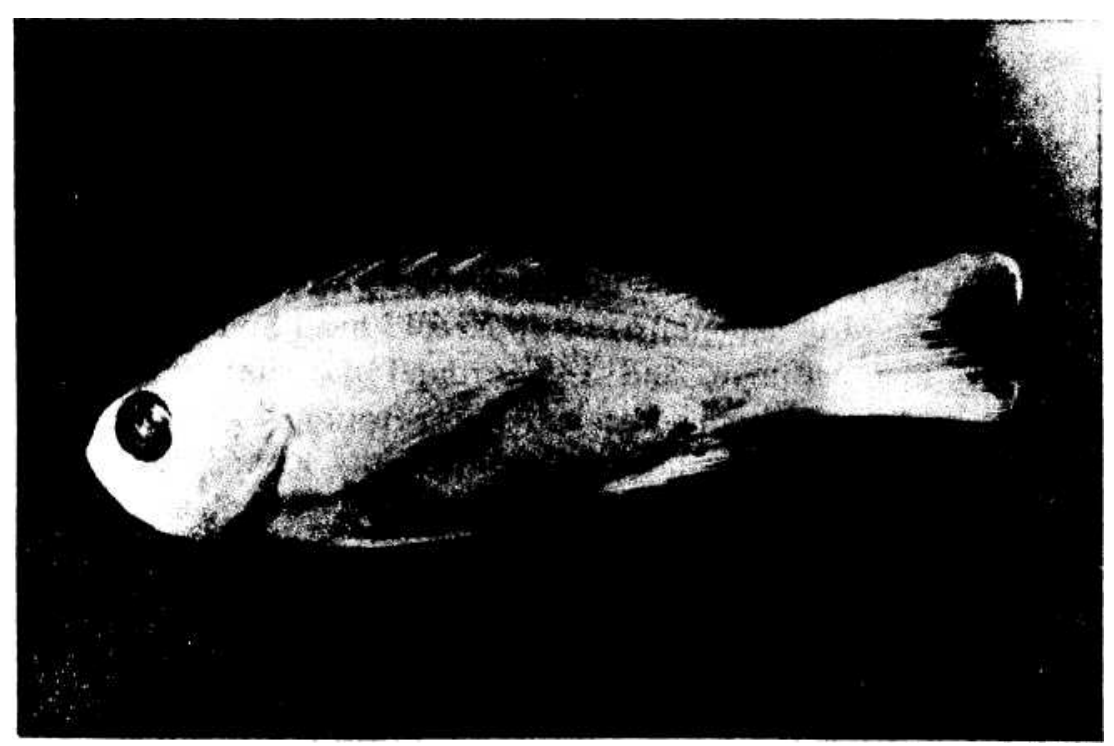

Figure 1. Anthias hutomoi n. sp.

Mouth oblique, terminally located, maxillary flared posteriorly and extending to a vertical through posterior portion of pupil; teeth of upper jaw consisting of inner band of depressible canines and outer band of larger fixed canines with enlarged tusk-like canine at front corner (visible externally when mouth is closed); additional pair of equally large teeth medial to and behind tusk-like teeth, these directed posteriorly and medially; lower jaw with large retorse tusk on each side of symphysis and smaller tusk at middle of each dentary; anterior part of lower jaw with band of very small canines terminating at about middle of dentary, then continuing as a single row of moderate sized canines posterior to tusk; vomer and palatines with narrow bands of small canines; pair of nasal openings on each side of snout; anterior nares about $1 / 2$ diameter 


\section{G. R. Allen \& Burhanuddin}

of posterior openings, with elevated rim, especially prominent on posterior edge. Head pores situated as follows: four on mandible; five to six on preorbital-suborbital; three on supraorbital, including two relatively close-set pairs on each side of interorbital space; two on each side of snout median to and slightly dorsal of large posterior nasal opening; one between anterior nasal opening and snout tip; series of inconspicuous pores across nape and from upper corner of eye to upper edge of gill opening.

Angle and hind edge of preopercle serrate; opercle series with a few weak serrae and two snout spines near upper corner; scales of head and body ctenoid; squamulae absent; base of spinous dorsal generally scaleless, although a few scales on membranous portion between posteriormost spines; scales present on basal portion of soft dorsal, anal, and covering most of caudal fin; maxilla scaled, without supplemental bone; predorsal scales extending to snout tip, anteriormost embedded in mucous layer and occasionally not apparent; head and body completely scaled except lips, isthmus, and area around nostrils; preopercle with four oblique scale rows and additional two rows on lower limb; circumpeduncular scales about 21; lateral-line gradually ascending from upper corner of gill opening to within three scale rows below about sixth dorsal spine, then gradually descending to middle of side of caudal peduncle where it continues in a straight line to base of caudal fin.

Dorsal spines gradually increasing in length to third spine, remainder of spines about equal or slightly decreasing in length; first dorsal spine 6.7 (5.7 to 6.0), third dorsal spine 2.5 (2.1 to 3.1), last dorsal spine 2.9 (2.6 to 2.8), longest soft dorsal ray 2.3 (1.9 to 2.3), all in head length; second anal spine stouter than first and third spines; first anal spine 6.4 (5.2 to 5.8), second anal spine 2.4 (2.1 to 2.4), third anal spine 2.6 (2.2 to 2.5), all in head length; pectoral fins more or less pointed, middle rays longest, 1,5 (1.0 to 1.2) in head length; pelvic fins with filamentous tips reaching to level of anterior anal rays, their length 0.8 (0.9 to 1.3) in head length; caudal fin crescentic or emarginate with outer rays elongate, their length 0.8 (0.9 to 1.0 ) in haed length.

Colour of holotype in alcohol: head and body largely uniform yellowish-tan except slightly dusky patch on interorbital; most of scales of upper part of sides with fine pepper-like spotting on their basal portion giving overall appearance of transverse streak on each side; fins uniformly pale.

Colour in life: head and body rosy-pink with yellowish fins. 


\section{ANTHIAS HUTOMO1}

Remarks

The generic classification of tropical Anthiinae is poorly understood. Most species have been assigned to Anthias BLOCH. However, KATAYAMA (1960) ressurrected Pseudanthias BLEEKER for several species formerly included in Anthias. He stated that Pseudanthias differs from Anthias in having the ventrals not produced in ribbon-like fashion, no small auxiliary scale and no distinct angle in the lateral-line. These characters seem to be of minor importance and we prefer to follow the example of HEEMSTRA (1973) in preserving the use of Anthias, at least until revisionary studies now in progress by HEEMSTRA and RANDALL are completed.

A. hutomoi is possibly allied to A. cichlops (BLEEKER 1853). Both species have two to three scales above the lateral-line, similar gill-raker counts, an acute anal fin tip, and a body depth of 2.9 to 3.0 in standard length. However, they differ in several important respects including counts for the soft dorsal fin (13 to 15 rays, usually 14 for hutomoi vs 16 rays for cichlops), pectoral fin (16 to 17 rays vs 18 to 19), and pored lateral-line scale (43 to 47 [over half of specimens with 46 or 47] vs 41 to 45 for cichlops). In addition, the head of hutomoi is longer (2.8 to 3.1 in standard length vs 3.4) and the caudal is lunate rather than deeply forked as in cichlops.

The species is named hutomoi in honour of Mr. MALIKUSWORO HUTOMO of the Lembaga Oseanologi Nasional, Jakarta, who assisted in collecting the type specimens.

\section{ACKNOWLEDGEMENTS}

We are grateful to Dr. Aprilani SoEgIARTO, Director of the Lembaga Oseanologi Nasional, Jakarta, for inviting us to participate in the Rumphius Expedition II. Thanks are also due to Dr. J. E. RANDALL and Mr. ONO K. SumADHIHARGA for their assistance with the Maluku fish collections. Financial assistance for the senior author's air fare was provided by the Food and Agriculture Organization (FAO) of the United Nations through the efforts of Dr. WALTER FISCHER (FAO, Rome).

\section{REFERENCES}

BLEEKER, P. 1853. Diagnostische beschrijvingen van nieuwe of weinig bekende vischsoorten van Sumatra. Tiental V-X. Nat. Tidschr. Ned. Indie 4: 243-302.

Heemstra, P. C. 1973. Anthias conspicuus sp. nova (Perciformes: Serranidae) from the Indian Ocean, with comments on related species. Copeia 2: 200-210.

Katayama, M. 1960. Fauna Japonica. Serranidae (Pisces). Biogeographical Soc. Japan: $152-158$. 


\section{G. R. Allen \& Burhanuddin}

Table I. Morphometric proportions (in thousandths of the standard length) of selected types of Anthias hutomoi

CHARACTERS

\begin{tabular}{cccc}
\multicolumn{2}{c}{ Holotype } & \multicolumn{2}{c}{ Paratypes } \\
LON & WAM & LON & LON \\
NCIP. 3493 & P25199-001 & NCIP. 3495 & NCIP. 3496
\end{tabular}

\begin{tabular}{lrrrr} 
Standard length (mm) & 51.0 & 48.7 & 38.5 & 34.4 \\
Greatest body depth & 333 & 350 & 337 & 343 \\
Greatest body width & 186 & 175 & 182 & 169 \\
Head length & 329 & 318 & 358 & 334 \\
Snout length & 78 & 72 & 78 & 64 \\
Eye diameter & 106 & 113 & 125 & 119 \\
Interorbital width & 104 & 90 & 91 & 87 \\
Length of maxillary & 137 & 154 & 161 & 151 \\
Least depth of caudal peduncle & 133 & 133 & 130 & 122 \\
Length of caudal peduncle & 137 & 133 & 143 & 122 \\
Snout to origin of dorsal fin & 313 & 324 & 338 & 349 \\
Snout to origin of anal fin & 647 & 650 & 675 & 640 \\
Snout to origin of pelvic fin & 373 & 353 & 431 & 349 \\
Length of dorsal fin base & 549 & 590 & 571 & 600 \\
Length of anal fin base & 153 & 164 & 182 & 166 \\
Length of pectoral fin & 216 & 308 & 317 & 320 \\
Length of pelvic fin & 402 & 339 & 286 & 265 \\
Length of 1st dorsal spine & 49 & 55 & 60 & 58 \\
Length of 3rd dorsal spine & 133 & 148 & 117 & 122 \\
Length of last dorsal spine & 112 & 123 & 128 & 119 \\
Longest soft dorsal ray & 141 & 164 & 169 & 145 \\
Length of 1st anal spine & 51 & 62 & 68 & 58 \\
Length of 2nd anal spine & 137 & 154 & 156 & 151 \\
Length of 3rd anal spine & 127 & 147 & 145 & 140 \\
Longest soft anal ray & 255 & 205 & 203 & 174 \\
Length of caudal fin & 411 & 349 & 351 & 377 \\
\hline & & & & \\
\hline
\end{tabular}

